\title{
Efficacy of Double Nickel LC (Bacillus amyloliquefaciens D747 Strain) for Management of White Mold in Snap and Dry Bean
}

\author{
Sarah J. Pethybridge, ${ }^{1,+}$ Beth K. Gugino, ${ }^{2}$ and Julie R. Kikkert ${ }^{3}$ \\ ${ }^{1}$ Plant Pathology \& Plant-Microbe Biology Section, School of Integrative Plant Science, Cornell AgriTech at The New York State Agricultural \\ Experiment Station, Cornell University, Geneva, NY, 14456; ${ }^{2}$ Department of Plant Pathology and Environmental Microbiology, The \\ Pennsylvania State University, University Park, PA 16802; and ${ }^{3}$ Cornell Cooperative Extension, Canandaigua, NY, 14424
}

Accepted for publication 24 February 2019.

\section{Abstract}

White mold caused by Sclerotinia sclerotiorum is a serious disease affecting snap and dry bean production. Management is reliant upon fungicides to protect flowers from infection by ascospores. The inability to use conventional fungicides in organic production represents a substantial hurdle, although products approved by the National Organic Program (NOP) offer a substitute for disease management. In many cases, copper-based products are central to disease management programs in organic production, but the potential for crop loss from premature flower abscission in snap and dry bean owing to phytotoxicity when applied at high temperatures and for other undesirable environmental outcomes has driven interest in biopesticides registered by the NOP as alternatives. Five small-plot, replicated field trials (three in snap bean and two in light red kidney bean) were conducted across three years (2016 to 2018) to evaluate the efficacy of the biopesticide Double Nickel LC (Bacillus amyloliquefaciens D747 strain) for the management of white mold. Trials were inoculated with S. sclerotiorum ascospores to ensure uniform disease potential. The incidence of white mold in plots receiving two applications of Double Nickel LC (2.34 liters/ha) was not significantly different from the conventional fungicide standards. No significant difference in white mold incidence was found between 2.34 and 4.68 liters/ha of Double Nickel LC in either crop. Responses in pod yield components from improved white mold management in either crop were variable. The potential of Double Nickel LC for use in organic production of snap and light red kidney bean for management of white mold is discussed.

Keywords: Bacillus amyloliquefaciens, snap bean, kidney bean, white mold, Sclerotinia sclerotiorum, organic production
White mold caused by the fungus Sclerotinia sclerotiorum (Lib.) de Bary is an important disease of leguminous crops including snap and dry bean across the United States (Bolton et al. 2006; Peltier et al. 2012) and can be severe in the relatively mild and wet summers of the northeastern United States, including New York (NY) (Lehner et al. 2017). In western and central NY, snap beans are an important broad-acre vegetable grown in intensive cropping rotations with other vegetable and field crops, and in 2014, snap beans were grown on approximately 12,400 ha. Similarly, dry bean (predominantly light and dark red kidney and black turtle beans) were grown on approximately 3,230 ha (USDA-NASS 2017). Direct losses to snap and dry bean production from white mold result from ascosporic infection of the flowers that leads to reductions in pod numbers. Mycelia and sclerotia that remain attached to the pods and plants are also a harvest contaminant and can incur additional costs in postharvest processing (Peltier et al. 2012; Shah

${ }^{\dagger}$ Corresponding author: S. J. Pethybridge; E-mail: sjp277@ cornell.edu

Funding: This project was funded by the New York State Vegetable Research Council and Association; the Pennsylvania State Vegetable Growers Association, and the United States Department of Agriculture, National Institute of Food and Agriculture Hatch projects NYG-625424 and PEN04632-1013768, managed by The New York Agricultural Experiment Station, Cornell University, Geneva, NY, and The Pennsylvania State University, respectively.

The author(s) declare no conflict of interest.

(C) 2019 The American Phytopathological Society et al. 2002). Secondary infections of the stems may result in canopy collapse, making mechanical harvest problematic, and conditions suitable for sunscald (MacMillan 1918) and the spread of other pod diseases such as gray mold caused by Botrytis cinerea (Shah et al. 2002). The disease also has secondary impacts on profitability of cropping systems owing to the ability of the pathogen to cause disease on a broad range of vegetable and field crops (Boland and Hall 1994). For example, if a white mold epidemic has occurred, longer rotations with less profitable nonhost crops such as cereals or field corn may be required.

Effective management of white mold relies upon an integration of strategies to reduce sclerotial populations in the soil and in-season management tactics aimed to protect flowers from ascosporic infection. Management strategies reducing soilborne inoculum are generally incrementally effective because even low inoculum densities (one sclerotia per row meter of bean) may still result in significant crop loss (Wegulo et al. 2000). Findings from studies examining the interrelationships between tillage, sclerotial viability, and white mold incidence have been mixed. Tillage to invert the soil profile to bury sclerotia can temporarily remove inoculum from the top layer ( 2 to $3 \mathrm{~cm}$ ) of the soil, greatly reducing their ability to germinate and produce apothecia on the surface (Mueller et al. 2002; Williams and Stelfox 1980); however, this may have deleterious effects on soil physical structure and health (Bronick and Lal 2005). On the contrary, sclerotia can remain viable for at least 5 years at soil depths of 20 to $25 \mathrm{~cm}$, and in fields with high inoculum densities, therefore, regular tillage 
may continuously deliver new sclerotial populations to the surface (Peltier et al. 2012). Rotation to nonhost crops is an effective strategy for white mold, but the broad host range of the pathogen often leads to perpetuation of inoculum on weeds and volunteer hosts, diluting the potential benefits (Boland and Hall 1994; Tu 1997). Manipulation of agronomic practices such as nitrogenous fertilizer inputs to reduce plant vigor and crop density, widening the space between rows, and decreasing plant populations are also effective because of manipulation of microclimatic conditions but may have unacceptable trade-offs with yield and profitability (Coyne et al. 1974; Pynenburg et al. 2011). Despite the lack of resistant cultivars, in dry and snap bean, the selection of cultivars that are more upright and highly branched may be helpful if agronomic features are suitable and attainable yield competitive (Peltier et al. 2012).

The application of in-season products made during flowering for management of white mold is often prophylactic. In conventional bean production in NY, there are several fungicides from which to select, and the choice is largely based on cost (Hunter et al. 1978; Lehner et al. 2017; Shah et al. 2002). Studies investigating the potential factors responsible for the suboptimal management of white mold have discounted fungicide resistance (Lehner et al. 2017) and identified the importance of synchronicity with flowering in determinate snap bean cultivars (Pethybridge et al., unpublished data).

In NY, organic vegetable production is becoming increasingly popular in diversified small-farm and broad-acre systems. The inability to use conventional fungicides for management of white mold therefore represents a significant barrier to achieving high yields in organic snap and dry bean production. However, products with certification for use by the National Organic Program offer the ability to replace conventional fungicides for white mold and have potential to form an important part of the integrated disease management program for organic bean production. Of the products available for disease management in organic bean production, copper-based formulations pose a risk to flower survival and hence pod yield owing to the potential for interactions with high temperatures (Pethybridge, unpublished data), and repeated applications promote build-up of copper residues in the environment (Thakore 2006). Biopesticide materials containing microorganisms may act by suppressing pathogen development through direct competition or production of secondary, toxic metabolites or volatile compounds (Massawe et al. 2018; Thakore 2006). The identification of biopesticides with efficacy for white mold management may also be beneficial in conventional snap and dry bean production for rotation of products belonging to different Fungicide Resistance Action Committee (FRAC) groups (FRAC 2018). A shift toward reduced sensitivity to thiophanate-methyl in the NY $S$. sclerotiorum population has already been detected (Lehner et al. 2015), emphasizing that FRAC group rotation is important to prevent resistance development (Lehner et al. 2017). Gray mold is also a sporadic issue in snap and dry bean production in NY, and resistance to multiple FRAC groups is prevalent across pathosystems (Hahn 2014). Improved field access through shorter reentry times and preharvest intervals offered by biopesticides may also be especially beneficial to small-scale mixed farm enterprises (McGrath et al. 2010) and those direct retailing produce to the consumer.

The objective of this study was to evaluate the efficacy and robustness of Double Nickel LC (Bacillus amyloliquefaciens D747 strain) for the management of white mold in snap and dry bean production in NY. Double Nickel LC was selected because of moderate efficacy compared with conventional fungicides identified in a preliminary snap bean trial conducted in 2015 (Double Nickel 55; Pethybridge et al. 2016).

\section{Efficacy Trials}

Five small-plot, replicated field trials were conducted to evaluate the efficacy and rate of Double Nickel LC for management of white mold in snap and dry bean. One trial was conducted in snap bean cultivar Huntington in each of three years: 2016, 2017, and 2018. The remaining trials were in light red kidney bean cultivar California Early in 2016 and 2017. All trials were located at the Research North facility at Cornell AgriTech at The New York State Agricultural Experiment Station $\left(42^{\circ} 86^{\prime} \mathrm{N} ; 77^{\circ} 02^{\prime} \mathrm{E}\right)$. Trials were planted using a precision vacuum Monosem planter with $76 \mathrm{~cm}$ between rows and inrow spacings of 51 and 39 seeds/m for snap and light red kidney bean trials, respectively. For snap bean trials, $336.3 \mathrm{~kg} / \mathrm{ha} 15-5-10$ fertilizer was broadcast and incorporated 2 to 5 days prior to planting, and the same amount was banded at planting. For light red kidney bean trials, $448.3 \mathrm{~kg} / \mathrm{ha}$ of the same fertilizer was used in broadcast and banded applications. S-Metolachlor (Dual Magnum; Syngenta Crop Protection, Greensboro, NC) was applied for preemergent weed control within $24 \mathrm{~h}$ of planting at rates of 2.1 and 1.2 liters/ha for snap and light red kidney bean crops, respectively. Seeds of both crop species were treated with thiamethoxam (Cruiser 5FS, Syngenta Crop Protection) for insect management and with mefenoxam and fludioxonil (ApronMaxx, Syngenta Crop Protection) for management of seedling diseases. At 35 to 45 days after planting (DAP), $56.1 \mathrm{~kg} / \mathrm{ha}$ of ammonium nitrate was applied to promote plant growth and achieve a dense canopy. Supplemental irrigation was provided by overhead solid-set sprinklers to optimize plant growth and conditions for infection and disease development.

The experimental design in all trials was a randomized complete block and included five replications of each treatment. Plot dimensions were also identical across trials $(3.1 \mathrm{~m}$ long $\times 2$ rows). Plots were separated by $1.5 \mathrm{~m}$ within rows and two or four rows between blocks.

Products (Table 1) were applied with a carbon dioxidepressurized backpack sprayer at 250 to $265 \mathrm{kPA}$ fitted with four TeeJet 8002VS flat fan nozzles (Spraying Systems, Glendale Heights, IL) at volumes of 205.8, 233.8, and 215.1 liters/ha in trials conducted in 2016, 2017, and 2018, respectively. In each trial, a conventional fungicide and nontreated control were included. The choice of conventional fungicide reflected the most common product used by NY snap bean and dry bean growers in the previous year. Nozzles were spaced evenly at $48.3 \mathrm{~cm}$ on a $96.5-\mathrm{cm}$ boom to ensure uniform application of treatments across both rows of each plot. All products were applied with the spreader polysorbate20 (0.01\% v/v; as Tween-20; Sigma-Aldrich, St. Louis, MO). Two applications of each product were applied, coinciding with $10 \%$ (defined as $10 \%$ of plants with at least one open flower) and $100 \%$ flowering (all plants with at least one open flower). Plots were inoculated with $S$. sclerotiorum ascospores within $24 \mathrm{~h}$ following treatment application (Table 1).

$S$. sclerotiorum inoculum was prepared from ascospores stored on filter paper discs at $-20^{\circ} \mathrm{C}$ collected from sclerotia that had been induced to carpogenically germinate under in vitro conditions (Pethybridge et al. 2015). In brief, ascospores were scraped from the discs into sterile distilled water, and the concentration was quantified using a hemocytometer. Inoculum was applied with a backpack sprayer with $0.01 \% \mathrm{v} / \mathrm{v}$ polysorbate- 20 . The viability of each inoculum preparation was quantified by evaluating the germination of 100 ascospores after spreading $50 \mu \mathrm{l}$ of the suspension on three replicate $2 \%$ water agar (Hardy Diagnostics, Santa Maria, CA) plates. An ascospore was considered germinated if the germ tube was at least twice the length of the individual ascospore. The 
viability of ascospores in the inoculum used across trials was at least $97 \%$.

Soon after crop emergence (20 to 28 DAP), in-row plant density was quantified within each plot by counting the number of plants in each of two $1.5-\mathrm{m}$ sections of row. This was to evaluate homogeneity of the snap bean and light red kidney bean stands to exclude this as a potential covariate that may influence microclimatic conditions and, hence, white mold incidence across the trial areas. The effect of treatment on white mold incidence on pods and plants and on pod yield components at 56 to 65 DAP was evaluated. In each trial, plants were removed from two 1-m arbitrarily selected row lengths within each plot, and pods were manually removed and sorted into symptomatic and healthy. Diseased plants and pods were defined as those with white mold symptoms (bleached, necrotic lesions), sclerotia, and/or mycelia typical of S. sclerotiorum (Fig. 1A). The incidence $(\%)$ of white mold on plants and pods was calculated as a function of the total number of plants or pods per plot. Healthy pods from each plot were weighed and the number of pods counted, to calculate the average weight of individual healthy pods. In the snap bean trial conducted in 2018, the incidence of white mold on plants and pods was evaluated in situ and pod yield components were not measured, owing to damage from flooding.

Statistical analysis. The effect of treatment on the incidence of white mold on plants and pods, pod yield, weight of healthy pods, and average weight of a healthy pod was analyzed using generalized linear modeling using product and rate as the fixed main effect and replicate as the random effect. Exploratory data analysis suggested significant differences between means and nonhomogeneous variances from datasets between years, and hence the effect of treatment on the response variables was analyzed separately for each year and crop (snap bean and dry bean). Assumptions of normality and homoscedasticity were checked within trials by quantile-quantile plots, examination of histograms with an overlaid normality curve, and residual plots. When necessary, the Shapiro-Wilk test was used as a formal test of normality. Least square means $(P=0.05)$ were calculated to separate treatments through pairwise comparisons when treatment was significant $(P<$ $0.05)$. All statistical analyses were conducted within Genstat version 17.2 software (Hemel Hempstead, U.K.).

Efficacy of treatments on white mold incidence and bean yield. The incidence of white mold on plants and pods was high in nontreated control plots in all trials (Fig. 1B). In snap bean, the incidence of white mold on plants ranged between 44.7 and $60.0 \%$, and on pods between 10.3 and $49.0 \%$ (Table 2). White mold incidence was similar in nontreated control plots in the light red kidney bean trials, with up to 51.7 and $21.6 \%$ on plants and pods, respectively (Table 3 ). In both snap and light red kidney bean trials, treatment had a significant effect on the incidence of white mold on plants and pods, but effects on pod yield components were mixed (Tables 2 and 3 ).

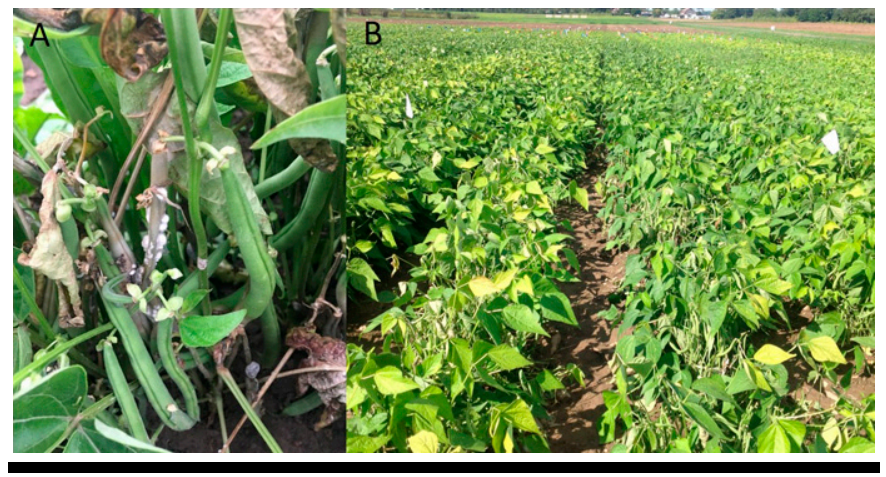

\section{FIGURE 1}

A, Symptoms of white mold and signs (mycelia and sclerotia) of Sclerotinia sclerotiorum on snap bean pods; and $\mathbf{B}$, snap bean plots affected by white mold caused by $S$. sclerotiorum in nontreated control plots in the foreground marked by white flags.

\begin{tabular}{|c|c|c|c|c|c|}
\hline $\begin{array}{l}\text { Products, ap } \\
\text { experiments }\end{array}$ & $\begin{array}{l}\text { tion rates, and Sclerotini } \\
\text { nanagement of white mo }\end{array}$ & $\begin{array}{c}\text { TABLE } 1 \\
\text { sclerotiorum ascospore inc } \\
\text { Id in snap }(2016,2017, \text { anc } \\
\text { Geneva, NYZ }\end{array}$ & $\begin{array}{l}\text { tion dates used in th } \\
\text { 8) and light red kidn }\end{array}$ & al & $\begin{array}{l}\text { replicated field } \\
16 \text { and } 2017) \text { at }\end{array}$ \\
\hline Snap bean (2016) & $\begin{array}{l}\text { Double Nickel LC ( } 2.34 \\
\text { and } 4.68 \text { liters/ha) }\end{array}$ & Certis USA, Columbia, MD & $\begin{array}{l}\text { Bacillus amyloliquefaciens } \\
\text { strain D747 }\end{array}$ & 44 & $40+47$ \\
\hline & Cercobin $(62.4 \mathrm{~g} / \mathrm{ha})$ & $\begin{array}{l}\text { FMC Corp., Philadelphia, } \\
\text { PA }\end{array}$ & Thiophanate-methyl & 1 & \\
\hline Snap bean (2018) & $\begin{array}{l}\text { Double Nickel LC } \\
(2.34 \text { liters/ha) }\end{array}$ & Certis USA & $\begin{array}{l}\text { B. amyloliquefaciens } \\
\text { strain D747 }\end{array}$ & 44 & $56+59$ \\
\hline $\begin{array}{l}\text { Light red kidney } \\
\text { bean }(2017)\end{array}$ & $\begin{array}{l}\text { Double Nickel LC ( } 2.34 \\
\text { and } 4.68 \text { liters/ha) }\end{array}$ & Certis USA & $\begin{array}{l}\text { B. amyloliquefaciens } \\
\text { strain D747 }\end{array}$ & 44 & $34+41$ \\
\hline & Endura $(70.1 \mathrm{~g} / \mathrm{ha})$ & $\begin{array}{l}\text { BASF, Research Triangle } \\
\text { Park, NC }\end{array}$ & Boscalid & 7 & \\
\hline
\end{tabular}

${ }^{\mathrm{z}}$ FRAC $=$ Fungicide Resistance Action Committee (http://www.frac.info/, FRAC 2018); and DAP = days after planting. Plots inoculated with $S$. sclerotiorum ascospores within $24 \mathrm{~h}$ of each product application. 
In the snap bean trials, Double Nickel LC significantly reduced the incidence of white mold on plants and pods (Table 2). For example, the incidence of white mold on plants was reduced between 70.1 and $97.8 \%$ in plots receiving Double Nickel LC at 2.34 liters/ha compared with nontreated control plots. Similarly, reductions in the incidence of white mold on pods ranged between 73.3 and $94.9 \%$ compared with nontreated control plots. In snap bean trials conducted in 2016 and 2017, the incidence of white mold

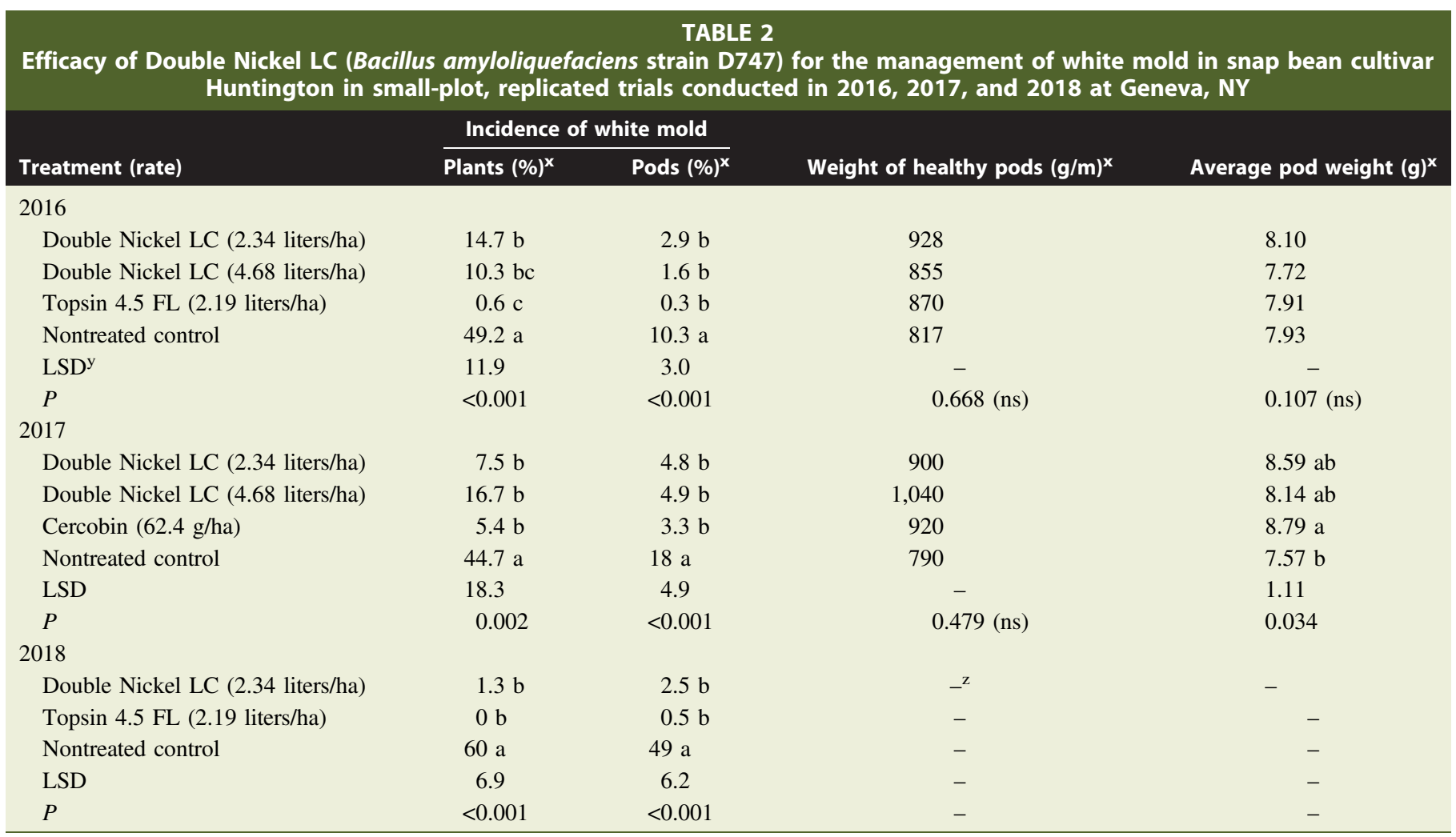

${ }^{\mathrm{x}}$ Means calculated with five replications per experiment. Means within columns followed by the same letter are not significantly different. $\mathrm{ns}=$ not significant.

${ }^{\mathrm{y}} \mathrm{LSD}=$ least significant difference $(P=0.05)$.

${ }^{\mathrm{z}}$ No data were collected.

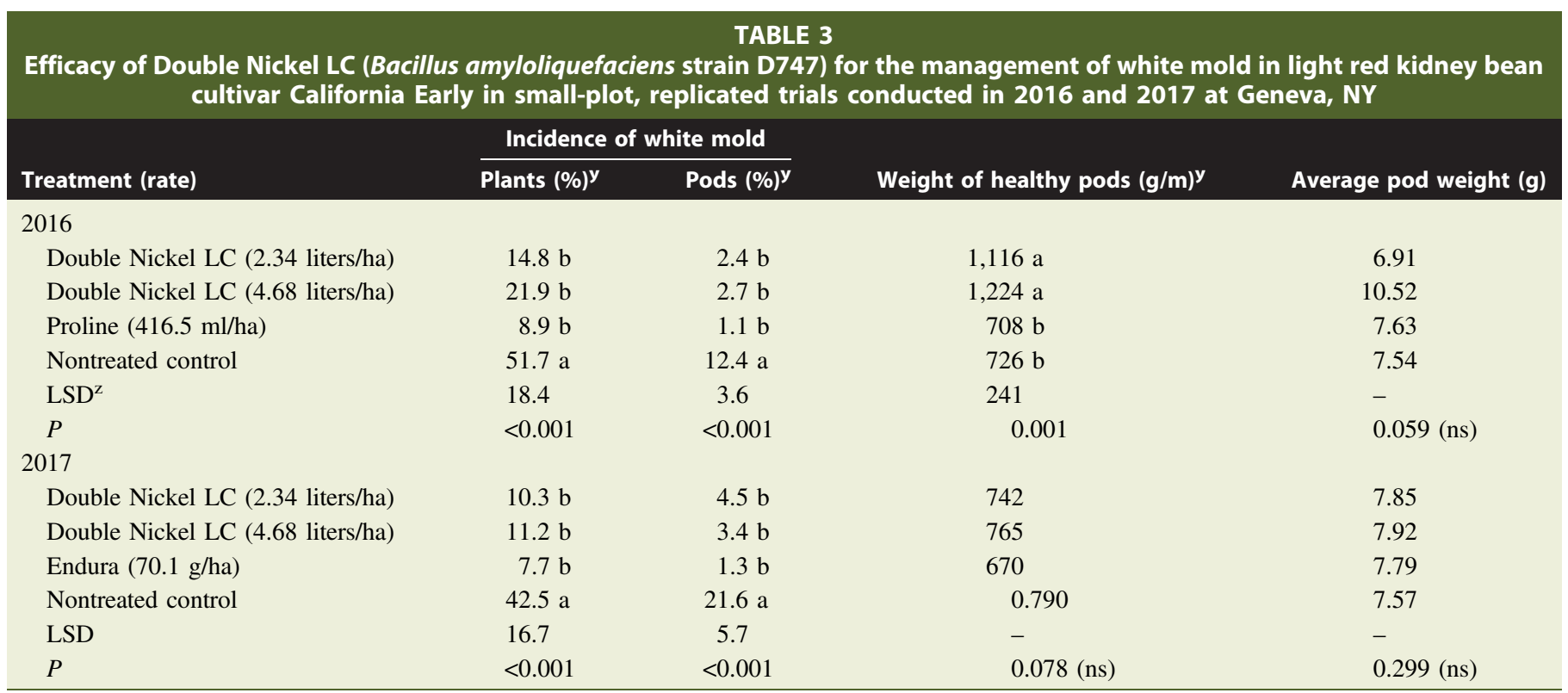

${ }^{\mathrm{y}}$ Means calculated with five replications per experiment. Means within columns followed by the same letter are not significantly different. ns $=$ not significant.

${ }^{\mathrm{z}} \mathrm{LSD}=$ least significant difference $(P=0.05)$. 
on plants and pods was not significantly different in plots receiving Double Nickel LC at either rate tested (2.34 and 4.68 liters/ha). The incidence of white mold on plants and pods was also not significantly different in plots receiving Double Nickel LC (2.34 liters/ha) and the conventional fungicide standard in each trial. Despite the significant reductions in white mold incidence, treatment had no significant effect on snap bean pod weight in either trial. The average weight of healthy pods was significantly increased in plots receiving the conventional fungicide standard compared with the nontreated control plots in the 2017 trial (Table 2).

In the light red kidney bean trials, Double Nickel LC (2.34 liters/ha) significantly reduced the incidence of white mold on plants compared with nontreated control plots by 71.4 and $75.8 \%$ in 2016 and 2017, respectively (Table 3). The incidence of white mold on pods was also significantly reduced by Double Nickel LC (2.34 liters/ha) compared with nontreated control plots in similar magnitudes to that described for the incidence of white mold on plants (average $=79.9 \%$ ). Moreover, the incidence of white mold on plants and pods was not significantly different between either rate of Double Nickel LC (2.34 and 4.68 liters/ha) and the conventional fungicide standard used in either trial. In the 2016 trial, pod weight was significantly increased in plots receiving Double Nickel LC at either rate by an average of $61.2 \%$ compared with nontreated control plots, but not significantly affected by treatment in the 2017 trial. The average weight of healthy pods was not significantly affected by treatment in either trial (Table 3 ).

\section{Conclusions}

This study has demonstrated the efficacy of the microbial biopesticide Double Nickel LC for reducing the incidence of white mold in snap and light red kidney bean in NY. In all five small-plot, replicated trials the efficacy of Double Nickel LC at a rate of 2.34 liters/ha was not significantly different from the conventional fungicide standard. Inoculation of trials with $S$. sclerotiorum ascospores ensured efficacy evaluations under high and homogenous disease pressure. In grower fields, the highly localized foci of white mold across pod- and plant-level hierarchies (Shah et al. 2017, 2018) that are generally spatially associated with the presence of apothecia and hence ascospores (Pethybridge et al. 2010) make commercial-scale cost-benefit analyses of products particularly challenging. Spatial heterogeneity in agronomic factors such as soil type and moisture and nutrient availability may further compound variation in plant growth, flowering onset, and duration (Yuan et al. 2017), which may also impact resultant disease management obtained in commercial bean fields.

Double Nickel LC is registered for use in certified organic production, and in these trials two applications at a rate of 2.34 liters/ha for white mold management in snap and light red kidney bean were applied. Although we did not investigate the optimal timings of Double Nickel LC, application of conventional fungicides relative to flowering stage to protect flowers from ascosporic infection is critical to managing white mold in indeterminate and determinate bean crops (Berger-Neto et al. 2017; Hunter et al. 1978; Morton and Hall 1989; McCreary et al. 2016; Mueller et al. 2004). The antifungal activity of Bacillus spp. for the biocontrol of $S$. sclerotiorum has been described in several studies. For example, Hou et al. (2006) described the potential of Bacillus spp. to reduce viability of $S$. sclerotiorum sclerotia, and different strains of $B$. subtilis have been associated with improved white mold control (Gao et al. 2014; Hu et al. 2005). The antagonistic activity of B. amyloliquefaciens subsp. plantarum on S. sclerotiorum has been attributed to inhibition of mycelial growth, suppression of sclerotial formation, reduced ascospore germination, and induction of structural abnormalities within the apothecia owing to hydrolytic enzymes, antibiosis, and plant growth-promotional activity (Rahman et al. 2016). In another study, application of an alternative B. amyloliquefaciens strain (D727) marketed as Stargus (Marrone Bio Innovations, Davis, CA) for use in specialty crops was more effective against white mold in snap bean if synchronized with early flowering, and an additional application in late flowering was beneficial (Pethybridge et al., unpublished data). Additional research is necessary to determine usage patterns of Double Nickel LC in indeterminate and determinate bean species to achieve optimal white mold management and conduct thorough cost-benefit analyses. Considering the excellent and reliable reduction in white mold incidence obtained from Double Nickel LC in snap and light red kidney bean, application of this product may be relatively more efficacious for white mold management in organic production than primarily relying upon cultural strategies to incrementally reduce soilborne sclerotial inoculum. However, ideally an integrated management plan should be promoted that includes cropping rotations with a high frequency of nonhosts (i.e., cereal and corn) to promote degradation by naturally occurring soil microbiota (Bolton et al. 2006). The decision to use either conventional fungicides or products approved by the Organic Materials Review Institute for in-season management of white mold should also thoroughly evaluate disease risk based on canopy density and the selection of cultivars with avoidance traits such as upright and open bean cultivars (Bolton et al. 2006; Grau and Radke 1984; Peltier et al. 2012).

\section{Acknowledgments}

Thanks to Carol Bowden, Elizabeth Burbine, Alex Silva, Sean Murphy, and David Strickland (Cornell University, Geneva, NY; listed alphabetically by surname) for excellent technical support. We are also grateful to Greg Rogers (Certis USA) for advice and provision of Double Nickel for inclusion in the trials.

\section{Literature Cited}

Berger-Neto, A., de Souza Jaccoud-Filho, D., Wutzki, C. R., Tullio, H. E., Pierre, M. L. C., Manfron, F., and Justino, A. 2017. Effect of spray droplet size, spray volume and fungicide on the control of white mold in soybeans. Crop Prot. 92:190-197.

Boland, G. J., and Hall, R. 1994. Index of plant hosts of Sclerotinia sclerotiorum. Can. J. Plant Pathol. 16:93-108.

Bolton, M. D., Thomma, B. P. H. J., and Nelson, B. D. 2006. Sclerotinia sclerotiorum (Lib.) de Bary: Biology and molecular traits of a cosmopolitan pathogen. Mol. Plant Pathol. 7:1-16.

Bronick, C. J., and Lal, R. 2005. Soil structure and management: A review. Geoderma 124:3-22.

Coyne, D. P., Steadman, J. R., and Anderson, F. N. 1974. Effect of modified plant architecture of Great Northern dry bean varieties (Phaseolus vulgaris) on white mold severity, and components of yield. Plant Dis. Rep. 58: 379-382.

Fungicide Resistance Action Committee (FRAC). 2018. FRAC Code list 2018: Fungicides sorted by mode of action (including FRAC code numbering). http://www.phi-base.org/images/fracCodeList.pdf.

Gao, X., Han, Q., Chen, Y., Qin, H., Huang, L., and Kang, Z. 2014. Biological control of oilseed rape Sclerotinia stem rot by Bacillus subtilis strain Em7. Biocontrol Sci. Technol. 24:39-52.

Grau, C. R., and Radke, V. L. 1984. Effects of cultivars and cultural practices on Sclerotinia stem rot of soybean. Plant Dis. 68:56-58.

Hahn, M. 2014. The rising threat of fungicide resistant in plant-pathogenic fungi: Botrytis as a case study. J. Chem. Biol. 7:133-141.

Hou, X., Boyetchko, S. M., Brkic, M., Olson, D., Ross, A., and Hegedus, D. 2006. Characterization of the anti-fungal activity of a Bacillus spp. associated with sclerotia from Sclerotinia sclerotiorum. Appl. Microbiol. Biotechnol. 72: 644-653.

Hu, X., Roberts, D. P., Jiang, M., and Zhang, Y. 2005. Decreased incidence of disease caused by Sclerotinia sclerotiorum and improved plant vigor of oilseed rape with Bacillus subtilis Tu-100. Appl. Microbiol. Biotechnol. 68: 802-807. 
Hunter, J. E., Abawi, G. S., and Grosier, D. C. 1978. Effects of timing, coverage, and spray oil on control of white mold of snap bean with benomyl. Plant Dis. Rep. 62:633-637.

Lehner, M. S., Kikkert, J. R., Gugino, B., and Pethybridge, S. J. 2017. Sensitivity and efficacy of boscalid, fluazinam, and thiophanate-methyl for white mold control in snap bean in New York. Plant Dis. 101:1253-1258.

Lehner, M. S., Paula Júnior, T. J., Silva, R. A., Vieira, R. F., Carneiro, J. E. S., Schnabel, G., and Mizubuti, E. S. G. 2015. Fungicide sensitivity of Sclerotinia sclerotiorum: A thorough assessment using discriminatory dose, $\mathrm{EC}_{50}$, high-resolution melting analysis, and description of new point mutation associated with thiophanate-methyl resistance. Plant Dis. 99:1537-1543.

MacMillan, H. G. 1918. Sunscald of beans. J. Agric. Res. 13:647-656.

Massawe, V. C., Hanif, A., Farzand, A., Mburu, D. K., Ochola, S. O., Wu, L., Tahir, H. A. S., Gu, Q., Wu, H., and Gao, X. 2018. Volatile compounds of endophytic Bacillus spp. have biocontrol activity against Sclerotinia sclerotiorum. Phytopathology 108:1373-1385.

McCreary, C. M., Depuydt, D., Vyn, R. J., and Gillard, C. L. 2016. Fungicide efficacy of dry bean white mold [Sclerotinia sclerotiorum (Lib.) de Bary, causal organism] and economic analysis at moderate to high disease pressure. Crop Prot. 82:75-81

McGrath, M., Vallad, G., and McSpadden-Gardener, B. 2010. Biopesticides for plant disease management in organic farming. eXtension. https://articles. extension.org/pages/29380/biopesticides-for-plant-disease-management-inorganic-farming.

Morton, J. G., and Hall, R. 1989. Factors determining the efficacy of chemical control of white mold in white bean. Can. J. Plant Pathol. 11:297-302.

Mueller, D. S., Bradley, C. A., Grau, C. R., Gaska, J. M., Kurle, J. E., and Pedersen, W. L. 2004. Application of thiophanate-methyl at different host growth stages for management of Sclerotinia stem rot in soybean. Crop Prot. 23:983-988.

Mueller, D. S., Dorrance, A. E., Derksen, R. C., Ozkan, E., Kurle, J. E., Grau, C. R., Gaska, J. M., Hartman, G. L., Bradley, C. A., and Pedersen, W. L. 2002. Efficacy of fungicides on Sclerotinia sclerotiorum and their potential for control of Sclerotinia stem rot on soybean. Plant Dis. 86:26-31.

Peltier, A. J., Bradley, C. A., Chilvers, M. I., Malvick, D. K., Mueller, D. S., Wise, K. A., and Esker, P. D. 2012. Biology, yield loss and control of Sclerotinia stem rot of soybean. J. Integr. Pest Manag. 3:B1-B7.

Pethybridge, S. J., Cobb, A. C., and Dillard, H. R. 2015. Production of apothecia and ascospores of Sclerotinia sclerotiorum. The Plant Health Instructor. Updated 2015. doi: 10.1094/PHI-T-2004-0604-01.
Pethybridge, S. J., Hay, F. S., and Gent, D. H. 2010. Characterization of the spatiotemporal attributes of Sclerotinia flower blight epidemics in a perennial pyrethrum pathosystem. Plant Dis. 94:1305-1313.

Pethybridge, S. J., Maloney, E. C., Bowden, C., and Kikkert, J. R. 2016. Efficacy of fungicides for the control of white mold in processing snap bean, 2015 . Plant Dis. Man. Rep. 10:V004.

Pynenburg, G. M., Sikkema, P. H., Robinson, D. E., and Gillard, C. L. 2011. The interaction of annual weed and white mold management systems for dry bean production in Canada. Can. J. Plant Sci. 91:587-598.

Rahman, M. M. E., Hossain, D. M., Suzuki, K., Shiiya, A., Suzuki, K., Dey, T. K., Nonaka, M., and Harada, N. 2016. Suppressive effects of Bacillus spp. on mycelia, apothecia and sclerotia formation of Sclerotinia sclerotiorum and potential as biological control of white mold on mustard. Austral. Plant Pathol. 45:103-117.

Shah, D. A., Dillard, H. R., and Cobb, A. C. 2002. Alternatives to vinclozolin (Ronilan) for controlling gray and white mold on snap bean pods in New York. Plant Health Prog. 3. doi: 10.1094/PHP-2002-0923-01-RS

Shah, D. A., Dillard, H. R., and Pethybridge, S. J. 2017. Probability distributions for marketable pods and white mould in snap bean. Ann. Appl. Biol. 171: 179-189.

Shah, D. A., Dillard, H. R., and Pethybridge, S. J. 2018. Hierarchical models for white mould in snap bean. Plant Pathol. 67:145-155.

Thakore, Y. 2006. The biopesticide market for global agriculture use. Ind. Biotechnol. (New Rochelle N.Y.) 2:194-208.

Tu, J. C. 1997. An integrated control of white mold (Sclerotinia sclerotiorum) of beans, with emphasis on recent advances in biological control. Bot. Bull. Acad. Sin. 38:73-76.

U.S. Department of Agriculture, National Agricultural Statistics Service (USDA-NASS). 2017. 2016-2017 Agricultural Statistics Annual Bulletin. New York. USDA-NASS, Washington, DC.

Wegulo, S. N., Sun, P., Martinson, C. A., and Yang, X. B. 2000. Spread of Sclerotinia stem rot of soybean from area and point sources of apothecial inoculum. Can. J. Plant Sci. 80:389-402.

Williams, J. R., and Stelfox, D. 1980. Influence of farming practices in Alberta on germination and apothecium formation of sclerotia in Sclerotinia sclerotiorum. Can. J. Plant Pathol. 2:169-172.

Yuan, M., Ruark, M. D., and Bland, W. 2017. A simple model for snap bean (Phaseolus vulgaris L.) development, growth, and yield in response to nitrogen. Field Crops Res. 211:125-136. 